\title{
Syphilis Seroprevalence and Associated Risk Factors in HIV-infected Individuals
}

\author{
HIV ile Enfekte Bireylerde Sifiliz Seroprevalansı ve Ilişkili Risk Faktörleri
}

\begin{abstract}
(1) Ramazan KORKUSUZ, (1) Sevtap ŞENOĞLU
University of Health Sciences Turkey, Istanbul Bakırköy Dr. Sadi Konuk Training and Research Hospital, Clinic of Infectious Diseases and Clinical Microbiology, Istanbul, Turkey
\end{abstract}

\section{Abstract}

Introduction: Syphilis co-infection is common in patients living with human immunodeficiency virus (HIV)/AIDS due to the common route of transmission. In Turkey, both syphilis and HIV seroprevalences have been increasing in recent years. In our study, it was aimed to evaluate the risk factors related to syphilis co-infection in patients with HIV/AIDS who were followed up in our outpatient clinic.

Materials and Methods: Newly diagnosed 1057 patients with HIV/AIDS in our clinic between January 2015 and June 2019 were included in the study. Demographic features of the patients, physical examination findings, CD4+ T lymphocyte count, HIV-RNA level, Venereal Disease Research Laboratory and Treponema pallidum hemagglutination assay test results were analyzed retrospectively. Treponema pallidum hemagglutination assay positivity was accepted as an indicator of encountering with $T$. pallidum which caused syphilis.

Results: The mean age of the 1057 HIV-infected patients included in the analysis was $36.03 \pm 11.49$; the mean CD4+ T lymphocyte count was $434.5 \pm 255.4 / \mathrm{mm}^{3}, 963(91.1 \%)$ of them were male and 41.4\% graduated from university. It was found that 573 of the patients (54.3\%) were men who had sex with men (MSM). Treponema pallidum hemagglutination assay positivity were detected in 194 (18.3\%) of the patients and 190 (97.9\%) patients who encountered with T. pallidum were male $(p<0.001)$. It was found that $22 \%$ of MSM and $14 \%$ of heterosexual patients encountered with T. pallidum $(\mathrm{p}<0.001)$. While $90.2 \%$ of the patients did not use condoms in each intercourse, $25.1 \%$ stated that they only used it with their legal spouse and for contraception.

Conclusion: Sexual contact is the most common route of transmission for both HIV and syphilis. The seroprevalence of syphilis is relatively high in HIV-infected individuals. Among HIV-infected individuals, MSM constitute the group with the highest risk of syphilis. Therefore, syphilis should be screened and treated specifically during the diagnosis of HIV infection and in case of high-risk behaviors.

Keywords: HIV, syphilis, co-infection, seroprevalence

Giriş: Sifiliz koenfeksiyonu insan immün yetmezlik virüsü (HIV)/AIDS tanılı hastalarda ortak bulaşma yolu nedeniyle sık görülmektedir. Türkiye'de son yıllarda hem HIV hem de sifiliz seroprevalansı artmaktadır. Çalışmamızda polikliniğimizden takipli HIV/AIDS tanılı hastalarda sifiliz koenfeksiyonu ile ilgili risk faktörlerinin belirlenmesi amaçlanmıştır.

Gereç ve Yöntem: Çalışmaya Ocak 2015-Haziran 2019 döneminde kliniğimizde yeni tanı alan 1057 HIV/AIDS tanılı hasta dahil edilmiştir. Hastaların demografik özellikleri, fizik muayene bulguları, CD4+ T lenfosit sayısı, HIV-RNA düzeyi, Zührevi Hastalık Araştırma Laboratuvarı (Venereal Disease Research Laboratory-VDRL) ve Treponema pallidum hemaglütinasyon testi (TPHA) sonuçları retrospektif olarak incelenmiştir. Treponema pallidum hemaglütinasyon testi pozitifliği, sifilize neden olan T. pallidum ile karşılaşma göstergesi olarak kabul edilmiştir.

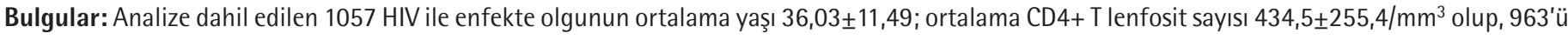
$(\% 91,1)$ erkek ve \%41,4'ü üniversite mezunudur. Hastaların 573'ünün $(\% 54,3)$ erkeklerle seks yapan erkekler (ESE) olduğu saptanmıştır. Hastaların 194'ünde $(\% 18,3)$ TPHA pozitifliği mevcut olup, T. pallidum ile karşılaşan hastaların 190'ı $(\% 97,9)$ erkektir ( $<<0,001)$. ESE olguların \%22'sinin ve

Cite this article as: Korkusuz R, Şenoğlu S. Syphilis Seroprevalence and Associated Risk Factors in HIV-infected Individuals. Mediterr J Infect Microb Antimicrob. 2020;9:13. 
heteroseksüel olguların \%14'ünün T. pallidum ile karşılaştığı saptanmıştır ( $p<0,001)$. Hastaların \%90,2'si kondomu her ilişkide kullanmıyorken, $\% 25,1$ 'i ise sadece yasal eşi ve doğum kontrolü için kullanmakta olduğunu belirtmiştir.

Sonuç: Cinsel temas hem HIV hem sifiliz için en yaygın bulaşma yolu olup, HIV ile enfekte bireylerde sifiliz seroprevalansı nispeten yüksek bulunmaktadır. İnsan immün yetmezlik virüsü ile enfekte kişiler arasında ise ESE sifiliz riski en yüksek grubu oluşturmaktadırlar. Bu nedenle, HIV enfeksiyonunun ilk tanısı sırasında ve bulaş açısından yüksek riskli davranışlar durumunda sifiliz özellikle taranmalı ve tedavi edilmelidir.

Anahtar Kelimeler: HIV, sifiliz, koenfeksiyon, seroprevalans

\section{Introduction}

The transmission routes of syphilis which is caused by Treponema pallidum and the transmission routes of human immunodeficiency virus (HIV) infection are similar. Infection caused by one of these microorganisms facilitates the transmission of the other. Impaired cellular and humoral immunity in HIV infection causes changes in the natural course of syphilis, progression of clinical findings, shortening of the incubation period, increased lesions and increased contagiousness of syphilis ${ }^{[1-3]}$. In addition, HIV transmission risk is higher, especially in HIV-infected individuals with early stage syphilis due to higher rates of genital/oral ulcers, decreased CD4+ T Iymphocyte count and increased HIV-RNA ${ }^{[4]}$.

In contrast to the situation in the world, the number of patients newly infected with HIV in Turkey is increased 5-fold in the last five years and the number of patients defined from 1985 until November 30, 2019 was 24 209. Two thirds of those patients were diagnosed in the last five years ${ }^{[5]}$. The main transmission routes of HIV infection in Turkey is sexual contact and transmissions via vertical route, intravenous drug use, blood transfusion, and percutaneous route are very limited. Among the patients newly infected with HIV in our country, it is noteworthy that the rate of males who have sexual course with males (MSM) has increased from 8\% to 14.79\% between 2013 and 2019 ${ }^{[5]}$. It has been reported that the incidence of syphilis in MSM has increased in the world since 2000 with the increase of risky sexual behaviors such as unprotected sex (oral and anal), sex with multiple partners, and especially sex under the influence of methamphetamine ${ }^{[6-8]}$.

In various studies conducted in Turkey, syphilis seroprevalence is shown as $0.07-0.4 \% 0^{[9-12]}$. High rates of HIV/syphilis coinfection are seen especially among MSM, due to the common transmission routes of HIV and syphilis and the increased contagiousness of one of them in the presence of the other one ${ }^{[13]}$. Therefore, determining the seroprevalence and risk factors of syphilis in HIV-infected individuals shows what our goals will be in preventing the spread of these infections. For this purpose, we investigated the seroprevalence of syphilis and associated risk factors in patients who were infected with HIV and followed up in our clinic.

\section{Materials and Methods}

This study was conducted with the approval of the Clinical Research Ethics Committee of Bakırköy Dr. Sadi Konuk Training and Research, University Health Sciences Turkey (protocol number: 2019/259, date: 10.06.2019).

One thousand fifty seven patients with HIV/AIDS who were diagnosed with the confirmation test after anti-HIV1/2 was detected by ELISA method in our clinic between January 2015 and June 2019 were included in our study. Patients' age, gender, education level, marital status, possible transmission route of HIV infection, condom use (in every intercourse), physical examination findings, CD4+ T lymphocyte count, HIV-RNA levels, Venereal Disease Research Laboratory (VDRL) and Treponema pallidum hemagglutination test (TPHA) results were analyzed retrospectively from files. Informed consent form was not obtained from the patients due to the retrospective study. The diagnostic criteria of the Center for Disease Control and Prevention (CDC) were used in the diagnosis of syphilis ${ }^{[14]}$. Primary syphilis was diagnosed in the presence of one or more ulcers/chancres; secondary syphilis was diagnosed in the presence of characteristic skin rash and mucocutaneous lesions with or without generalized lymphadenopathy; tertiary syphilis was diagnosed in the presence of cardiac findings, gums, tabes dorsalis, generalized paresis; and latent syphilis was diagnosed in patients with positive nontreponemal and treponemal tests without any clinical signs and symptoms. For the diagnosis of neurosyphilis in line with CDC recommendations; if clinical evidence of neurological involvement is observed (for example, cognitive dysfunction, motor or sensory deficits, ophthalmic or auditory symptoms, cranial nerve involvement, meningitis, or cerebrovascular involvement symptoms), a cerebrospinal fluid examination is required.

CD4+ T lymphocyte count was determined using standard flow cytometry (Beckman Coulter Inc., Fullerton, California, USA). Patients with a CD4+ T lymphocyte count below 350 cells/ 
$\mathrm{mm}^{3}$ were defined as patients with late presentation of HIV infection ${ }^{[15]}$. Level of HIV-RNA was measured by the polymerase chain reaction (PCR) method (real-time PCR, Rotor gene 0 , OIAGEN, Germany). Serum VDRL and TPHA tests were used for syphilis screening at the time of HIV diagnosis, at annual follow-up and in case of medical indication. TPHA positivity (with positive or negative VDRL) was accepted as an indicator of exposure to T. pallidum.

\section{Statistical Analysis}

The data of the research were evaluated using the SPSS 22. Number, percentage and mean, standard deviation and median were used for descriptive characteristics in statistical analysis of research data. The compliance of the data to normal distribution was examined with the Kolmogrov-Smirnov test. Arithmetic means of CD4+ T cell count, age and HIV-RNA levels were calculated. Also; independent sample T test, ANOVA, Fisher chi-square test and Yates chi-square test were used. A p value $<0.05$ was accepted as statistically significant.

\section{Results}

The mean age of the 1057 HIV- 1 infected patients included in the analysis was $36.03 \pm 11.49$ years; $963(91.1 \%)$ were male and $41.4 \%$ were university graduates. Of the patients, $573(54.3 \%)$ were MSM. Routine condom use of the patients was determined as $9.8 \%$. In the initial evaluation of the patients, mean CD4+T lymphocyte count was $434.5 \pm 255.4 / \mathrm{mm}^{3}$, and $419(39.6 \%)$ of the patients were diagnosed late.

It was found that $194(18.3 \%)$ of the patients we evaluated encountered T. pallidum. Of these, 145 (74.7\%) were positive for VDRL and TPHA, 49 (25.3\%) were negative for VDRL and positive for TPHA. Primary and secondary syphilis (early stage) were detected in $65(44.8 \%)$ of the patients who encountered T. pallidum. Among these 65 patients with early stage syphilis, 19 had multiple chancre, 40 had rash and seven had findings of syphilitic hepatitis. Tertiary syphilis was not observed in the patients.

Seventy eight of 194 patients who encountered T. pallidum were defined as HIV infected patients in the late period. Fifty four $(41.9 \%)$ of the patients diagnosed as having latent syphilis were found to be late-stage HIV-infected patients. Syphilis was detected in 178 of the patients at the time of HIV infection diagnosis and the seroprevalence was found to be $16.8 \%$. It was observed that syphilis co-infection developed during the follow-up of 16 MSM who did not have syphilis at the time of diagnosis while they were receiving antiretroviral therapy (ART).

The statistical relationships between syphilis seropositivity and age, gender, education level, marital status, HIV infection, condom use, CD4+ T lymphocyte count, and HIV-RNA levels are presented in Table 1. Of 194 patients with positive syphilis serology, $97.9 \%$ were male $(p<0.001), 66.3 \%$ of them were found to be MSM. It was found that MSM who came into contact with the agent of syphilis were younger than heterosexuals $(p<0.001)$ and $46 \%$ of them were university graduates $(p<0.001)$. The frequency of encountering T. pallidum was $126(22 \%)$ in 573 MSM and $68(14 \%)$ in 484 heterosexual patients $(p<0.001)$. While $90.2 \%$ of the patients did not use condoms in every intercourse, $25.1 \%$ stated that they only used it for their legal spouse and birth control. Statistical analyses between heterosexuals and MSM who encountered T. pallidum are presented in Table 2.

\section{Discussion}

Syphilis and HIV co-infection is common due to the common transmission routes and affect each other's course. Considering that syphilis is still a widespread infection and that HIV infection is also increasing among some countries, and progression of HIV infection is faster and more severe in syphilis-infected patients; timely diagnosis of syphilis/HIV co-infection is crucial. Syphilis seroprevalence in newly diagnosed HIV-infected patients has been reported as 25\% in Mexico, 21\% in Spain, 19.8\% in China, $15.7 \%$ in the USA, and $5.3 \%$ in $\operatorname{Iran}^{[16-20]}$. In our country, the seroprevalence of syphilis in HIV-infected patients is 2.5$25 \%{ }^{[21-24]}$. Syphilis seroprevalence of newly diagnosed patients was found to be $16.8 \%$ in our study. It is thought that the differences between centers are related with social, cultural and economic factors that vary according to the region and hospitals. The fact that VDRL and TPHA positivities were found together in 74.7\% of HIV-infected patients diagnosed as having syphilis in our study suggested that syphilis may have been acquired with HIV. In another study conducted in our country recently, rapid plasma reagin and TPHA tests of 91 of 97 patients with HIV/syphilis coinfection were found to be positive, and it was noted that there was an increase in number of patients aged 25-44 and $>65$ years, and that homosexual intercourse was determined as a risk factor ${ }^{[23]}$.

Almost all of our patients (97.9\%) who were exposed to syphilis were male and $66.3 \%$ of them were found to be MSM. In our study, it was observed that the seroprevalence of syphilis in MSM (22\%) was statistically higher than that of heterosexual men $(14 \%) \quad(p<0.001)$. A similar rate $(21.4 \%)$ was found in another study conducted in our country ${ }^{[22]}$. In a meta-analysis conducted in Western Europe, the seroprevalence of syphilis was reported as $14-59 \%{ }^{[25]}$ in HIV-infected MSM, and 22\% in a study conducted in China ${ }^{[18]}$.

Increasing number of partners show relative risk for syphilis seroprevalence ( $p=0.001$, Odd's ratio $=1.66)$, and the number of partners was found to be significantly higher in syphilis-coinfected MSM compared to heterosexuals $(p<0.001)$. 
The reason for the higher prevalence of syphilis in MSM compared to heterosexuals are having more than one sexual partner, widespread use of social media apps, and the use of stimulant drugs that increase sexual performance ${ }^{[7-9,26,27]}$.

The routine and correct use of condoms is very effective in protecting against HIV, syphilis and other sexually transmitted diseases $^{[28]}$. The frequency of patients who stated routine condom use in our study was only $9.8 \%$, and it was seen that routine condom use was mostly adopted after being infected with HIV. It was observed that this low rate of condom use was mostly for legal spouse and for contraception. In our study, no significant relationship was found between the frequency of syphilis and the use of condoms. In questioning the use of condoms in the patients, it was thought that the data could not be reliable because the use of drugs or alcohol made it difficult to remember.

Table 1. Syphilis serology and associated risk factors of human immunodeficiency virus-infected patients

\begin{tabular}{|c|c|c|c|c|c|}
\hline$n=1057$ & \multicolumn{2}{|c|}{$\begin{array}{l}\text { TPHA (-) }(n=863) \\
\text { (n) } \%\end{array}$} & \multicolumn{2}{|c|}{$\begin{array}{l}\text { TPHA (+) }(n=194) \\
(n) \%\end{array}$} & $\mathbf{p}$ \\
\hline \multicolumn{6}{|l|}{ Gender } \\
\hline Female & 90 & $10.4 \%$ & 4 & $2.1 \%$ & \multirow{2}{*}{$0.000^{*}$} \\
\hline Male & 773 & $89.6 \%$ & 190 & $97.9 \%$ & \\
\hline \multicolumn{6}{|l|}{ Age } \\
\hline $18-40$ & 609 & $70.6 \%$ & 129 & $66.5 \%$ & \multirow{3}{*}{0.388} \\
\hline $41-60$ & 224 & $25.9 \%$ & 55 & $28.4 \%$ & \\
\hline$>60$ & 30 & $3.5 \%$ & 10 & $5.1 \%$ & \\
\hline \multicolumn{6}{|l|}{ Education } \\
\hline Illiterate & 14 & $1.6 \%$ & 6 & $3 \%$ & \multirow{5}{*}{0.465} \\
\hline Primary school & 47 & $5.4 \%$ & 13 & $6.7 \%$ & \\
\hline Middle school & 225 & $26.1 \%$ & 56 & $28.9 \%$ & \\
\hline High school & 212 & $24.6 \%$ & 46 & $23.7 \%$ & \\
\hline University & 365 & $42.3 \%$ & 73 & $37.6 \%$ & \\
\hline \multicolumn{6}{|l|}{ Marital status } \\
\hline Single & 501 & $58 \%$ & 119 & $61.3 \%$ & \multirow{3}{*}{0.703} \\
\hline Married & 314 & $36.4 \%$ & 65 & $33.5 \%$ & \\
\hline Widow & 48 & $5.6 \%$ & 10 & $5.2 \%$ & \\
\hline \multicolumn{6}{|c|}{ Condom (in every sexual intercourse) } \\
\hline Yes & 82 & $9.5 \%$ & 22 & $11.3 \%$ & \multirow{2}{*}{0.425} \\
\hline No & 781 & $90.5 \%$ & 172 & $88.7 \%$ & \\
\hline \multicolumn{6}{|l|}{ Number of partners } \\
\hline$\leq 5$ & 460 & $53.3 \%$ & 79 & $40.7 \%$ & \multirow{2}{*}{$\begin{array}{l}0.001^{*} \\
0 R=1.66^{* *}\end{array}$} \\
\hline$>5$ & 403 & $46.7 \%$ & 115 & $59.3 \%$ & \\
\hline \multicolumn{6}{|l|}{ Transmission way } \\
\hline MSM & 447 & $51.8 \%$ & 126 & $65 \%$ & \multirow{2}{*}{$0.000^{*}$} \\
\hline HS & 416 & $48.2 \%$ & 68 & $35 \%$ & \\
\hline \multicolumn{6}{|l|}{ HIV-RNA (copy/mI) } \\
\hline$\leq 100.000$ & 349 & $40.44 \%$ & 76 & $39.17 \%$ & \multirow{2}{*}{0.745} \\
\hline$>100.000$ & 514 & $59.56 \%$ & 118 & $60.83 \%$ & \\
\hline \multicolumn{6}{|l|}{ CD4+ T Iymphocyte count } \\
\hline$\geq 350$ cells $/ \mathrm{mm}^{3}$ & 340 & $39.4 \%$ & 78 & $40.2 \%$ & \multirow{2}{*}{0.835} \\
\hline$<349$ cells $/ \mathrm{mm}^{3}$ & 523 & $60.6 \%$ & 116 & $59.8 \%$ & \\
\hline Average CD4+ count & \multicolumn{2}{|c|}{$431.54 \pm 8.612$} & \multicolumn{2}{|c|}{$447.66 \pm 19.106$} & 0.427 \\
\hline Average level of HIV-RNA & \multicolumn{2}{|c|}{$1777051.69 \pm 621529.064$} & \multicolumn{2}{|c|}{$625297.62 \pm 83808.893$} & 0.380 \\
\hline
\end{tabular}

${ }^{*}$ Fisher's exact test $p<0.05,{ }^{*} 0 \mathrm{R}$ : Odd's ratio.

MSM: Males having sex with males, HS: Heterosexual, TPHA: Treponema pallidum hemagglutination assay, HIV: Human immunodeficiency virus 
Table 2. Comparison of epidemiological characteristics in cases $(n=194)$ who encountered $T$. pallidum according to their sexual intercourse type

\begin{tabular}{|c|c|c|c|c|c|}
\hline$n=194$ & \multicolumn{2}{|c|}{ MSM $(n=126) \%$} & HS $(n=68) \%$ & \multicolumn{2}{|l|}{$\mathbf{p}$} \\
\hline \multicolumn{6}{|l|}{ Age } \\
\hline $17-40$ & 97 & $77 \%$ & 32 & $47 \%$ & \multirow{3}{*}{$0.000^{*}$} \\
\hline $41-60$ & 25 & $19.8 \%$ & 30 & $44.1 \%$ & \\
\hline$>60$ & 4 & $3.2 \%$ & 6 & $8.9 \%$ & \\
\hline \multicolumn{6}{|l|}{ Education } \\
\hline Illiterate & 2 & $1.6 \%$ & 4 & $5.9 \%$ & \multirow{5}{*}{$0.000^{*}$} \\
\hline Primary school & 5 & $3.4 \%$ & 8 & $11.7 \%$ & \\
\hline Middle school & 27 & $21.4 \%$ & 29 & $42.6 \%$ & \\
\hline High school & 34 & $27 \%$ & 12 & $17.6 \%$ & \\
\hline University & 58 & $46 \%$ & 15 & $22 \%$ & \\
\hline \multicolumn{6}{|l|}{ Marital status } \\
\hline Single & 98 & $77.8 \%$ & 21 & $30.9 \%$ & \multirow{3}{*}{0.957} \\
\hline Married & 23 & $18.2 \%$ & 42 & $61.8 \%$ & \\
\hline Widow & 5 & $4 \%$ & 5 & $7.3 \%$ & \\
\hline \multicolumn{6}{|c|}{ Condom (in every sexual intercourse) } \\
\hline Yes & 18 & $14 \%$ & 4 & $5.9 \%$ & \multirow{2}{*}{0.099} \\
\hline No & 110 & $86 \%$ & 64 & $94.1 \%$ & \\
\hline \multicolumn{6}{|c|}{ Number of partners (in the last six months) } \\
\hline$\leq 5$ & 39 & $31 \%$ & 40 & $58.8 \%$ & \multirow{2}{*}{$0.000^{*}$} \\
\hline$>5$ & 87 & $69 \%$ & 28 & $41.2 \%$ & \\
\hline
\end{tabular}

${ }^{*}$ Fisher's exact test $p<0.05$.

MSM: Males having sex with males, HS: Heterosexual

It was observed that $41.4 \%$ of our HIV-infected patients were university graduates and there was no significant relationship between the increase in education level and syphilis seroprevalence. It was found that MSM who came into contact with the agent of syphilis were younger than heterosexuals $(p<0.001)$ and $46 \%$ of MSM were university graduates $(p<0.001)$. HIV-infected MSM have higher awareness of sexually transmitted diseases, and it is seen that they have more frequent routine examinations and get diagnosed earlier. With early diagnosis, they are likely to be detected in the acute period. Despite the high level of education, HIV/syphilis infections may increase due to reasons such as starting early sexual life, having multiple partners and reluctance to use condoms.

In our study, although the education levels of MSM individuals were significantly higher than those of heterosexuals, regular condom use was not statistically significantly higher. Studies have shown that an HIV-infected individual who is under ART and has reached a level where HIV-RNA cannot be detected, has close to zero risk of sexually transmitting $\mathrm{HIV}^{[29-31]}$. As a result of these studies, the habit of not using condoms regularly in HIV-infected individuals on the grounds that there will be no HIV transmission may lead to the emergence of other sexually transmitted diseases. As a matter of fact, it was observed that syphilis co-infection developed during the follow-up of 16 HIVinfected MSM under ART.

Although the late-diagnosed HIV-infected patients had no history and symptoms of syphilis, $41.9 \%$ of them were found to have latent syphilis infection when they were first diagnosed as having HIV infection. This finding reveals that it is important to perform screening tests for syphilis regularly in HIV-infected individuals with a high risk of acquiring syphilis, even without symptoms.

The limitations of our study were the difficulty in remembering the use of condom in detail, not questioning the use of condom in oral sex, and not evaluating the presence of other sexually transmitted diseases together. Also, our study was a single center study, which was another limitation.

\section{Conclusion}

As a result, according to the profile of patients with HIV/AIDS in Turkey, the main route of transmission of HIV infection is seen as sexual contact. Since the possible transmission route of syphilis was sexual contact, HIV/syphilis co-infection was found 
at a high rate in our patient group. HIV-infected MSM were identified as the group with the highest risk of having syphilis. The higher prevalence of syphilis co-infection in MSM whose age is younger and whose education levels are higher, compared to heterosexuals, reveals the need for subject-specific training in risk groups. Determination of syphilis serology in all HIVinfected patients is critical for early recognition and treatment and is important to reduce the likelihood of further transmission of both infections.

\section{Ethics}

Ethics Committee Approval: This study was conducted with the approval of the Clinical Research Ethics Committee of Bakırköy Dr. Sadi Konuk Training and Research Hospital, University Health Sciences Turkey (protocol number: 2019/259, date: 10.06.2019).

Informed Consent: Informed consent form was not obtained from the patients due to the retrospective study.

Peer-review: Externally and internally peer-reviewed.

\section{Authorship Contributions}

Surgical and Medical Practices: R.K., Concept: R.K., Design: S.Ş., Data Collection or Processing: S.Ş., Analysis or Interpretation: R.K., Literature Search: S.Ş., Writing: R.K.

Conflict of Interest: No conflict of interest was declared by the authors.

Financial Disclosure: The authors declared that this study received no financial support.

\section{References}

1. Buchacz $K$, Patel P, Taylor M, Kerndt PR, Byers RH, Holmberg SD, Klausner JD. Syphilis increases HIV viral load and decreases CD4 cell counts in HIVinfected patients with new syphilis infections. AIDS. 2004;18:2075-9.

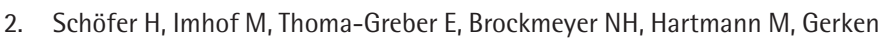
G, Pees HW, Rasokat H, Hartmann H, Sadri I, Emminger C, Stellbrink HJ, Baumgarten R, Plettenberg A. Active syphilis in HIV infection: a multicentre retrospective survey.The German AIDS Study Group (GASG). Genitourin Med. 1996;72:176-81.

3. 3.Phiri S, Zadrozny $S$, Weiss HA, Martinson F, Nyirenda $N$, Chen $C Y$, Miller WC, Cohen MS, Mayaud P, Hoffman IF. Etiology of genital ulcer disease and association with HIV infection in Malawi. Sex Transm Dis. 2013;40:923-8.

4. Jarzebowski W, Caumes E, Dupin N, Farhi D, Lascaux AS, Piketty C, de Truchis P, Bouldouyre MA, Derradji O, Pacanowski J, Costagliola D, Grabar $S$; FHDH-ANRS C04 Study Team. Effect of early syphilis infection on plasma viral load and CD4 cell count in human immunodeficiency virusinfected men: results from the FHDH-ANRS $\mathrm{CO} 4$ cohort. Arch Intern Med. 2012;172:1237-43.

5. Sağlık Bakanlığı Halk Sağlığı Genel Müdürlüğü Bulaşıcı Hastalıklar Daire Müdürlüğü. Last accessed date: 2019 Dec 23. Available from: https:// hsgm.saglik.gov.tr/tr/bulasici-hastaliklar/hiv-aids/hiv-aids-liste/hiv-aidsistatislik.html

6. Taylor MM, Aynalem G, Smith LV, Montoya J, Kerndt P. Methamphetamine use and sexual risk behaviours among men who have sex with men diagnosed with early syphilis in Los Angeles County. Int J STD AIDS. 2007;18:93-7.
7. Spindler HH, Scheer S, Chen SY, Klausner JD, Katz MH, Valleroy LA, Schwarcz SK.Viagra, methamphetamine, and HIV risk: results from a probability sample of MSM, San Francisco. Sex Transm Dis. 2007;34:586-91.

8. Wong W, Chaw JK, Kent CK, Klausner JD. Risk factors for early syphilis among gay and bisexual men seen in an STD clinic: San Francisco, 20022003. Sex Transm Dis. 2005;32:458-63.

9. Kirişci Ö, Aral M, Arıcan G , Muratdağı G . Bir Şehir Hastanesi Kan Transfüzyon Merkezine Başvuran Donörlerde HBV, HCV, HIV ve VDRL Seroprevalansı. Sakarya Tıp Dergisi. 2019;9:154-9.

10. Yildiz SM, Candevir A, Kibar F, Karaboga G, Turhan F, Kis C, Dincer S, Guvenc B. Hepatitis B, Hepatitis C, Human immunodeficiency virus and syphilis frequency among blood donors: A single center study. Transfus Apher Sci. 2015;53:308-14.

11. Köroğlu $M$, İçel $O$, Demiray $T$, Özbayraktar $S$, Akel N, Gün R, İnci F, Özgül $M$, Saraç M, Kuku i. Kan Bağışçıarında Tarama Test Sonuçlarının Yıllara Göre Değişimi; On Yıllık Değerlendirme, Malatya. OTSBD. 2016;1:1-7.

12. Ozturk G ,Yılmaz Z, Egici MT, Bektemur G. Evlilik öncesi danışmanlık ve rapor alma amacıyla aile hekimliği polikliniğine başvuran bireylerin değerlendirilmesi. Türkiye Aile Hekimliği Dergisi. 2019;23:92-101.

13. Centers for Disease Control and Prevention (CDC). Notes from the field: repeat syphilis infection and HIV coinfection among men who have sex with men-Baltimore, Maryland, 2010-2011. MMWR Morb Mortal Wkly Rep. 2013;62:649-50.

14. United States Centers for Disease Control and Prevention. Sexually Transmitted Disease Surveillance 2018. Last accessed date: 2020 0ct 11. Available from: https://www.cdc.gov/std/stats18/STDSurveillance2018-fullreport.pdf

15. Antinori A, Coenen T, Costagiola D, Dedes N, Ellefson M, Gatell J, Girardi E, Johnson M, Kirk O, Lundgren J, Mocroft A, D'Arminio Monforte A, Phillips A, Raben D, Rockstroh JK, Sabin C, Sönnerborg A, De Wolf F; European Late Presenter Consensus Working Group. Late presentation of HIV infection: a consensus definition. HIV Med. 2011;12:61-4.

16. Mata-Marin JA, Sandoval-Sánchez JJ, Huerta-Garcia G, Arroyo-Anduiza Cl, Alcalá-Martínez E, Mata-Marin LA, Sandoval-Ramirez JL, Gaytán-Martínez J. Prevalence of antibodies against Treponema pallidum among HIV-positive patients in a tertiary care hospital in Mexico. Int J STD AIDS. 2015;26:81-5.

17. Pérez CC, Cerón Al, Fuentes LG, Zañartu SC, Balcells MME, Ajenjo HC, Rabagliati BR, Labarca $\mathrm{D}$, Acuña LG. Hepatitis B, C, Treponema pallidum and Toxoplasma gondii co-infections in HIV infected patients. Rev Med Chil. 2009;137:641-8.

18. Hu QH, Xu JJ, Zou HC, Liu J, Zhang J, Ding HB, Qian HZ, Li SR, Liu Y, Jiang YJ, Shang $H$, Wang N. Risk factors associated with prevalent and incident syphilis among an HIV-infected cohort in Northeast China. BMC Infect Dis. 2014;14:658.

19. Bernstein KT, Stephens SC, Strona FV, Kohn RP, Philip SS. Epidemiologic characteristics of an ongoing syphilis epidemic among men who have sex with men, San Francisco. Sex Transm Dis. 2013;40:11-7.

20. Badie, Yavari Z, Esmaeeli S, Paydary K, Emamzadeh-Fard S, Seyedalinaghi $\mathrm{S}$, Rasoulinejad M. Prevalence survey of infection with Treponema pallidum among HIV-positive patients in Tehran. Asian Pac J Trop Biomed. 2013;3:334-6.

21. Sarigül $F$, Sayan $M$, İnan $D$, Deveci $A$, Ceran $N$, Çelen $M K$, Çağatay $A$ Özdemir HÖ, Kuşcu F, Karagöz G, Heper Y, Karabay O, Dokuzoğuz B, Kaya S, Erben N, Karaoğlan I, Ersöz GM, Günal Ö, Hatipoğlu Ç, Kutlu SS, Akbulut A, Saba R, Şener A, Büyüktuna SA. Current status of HIV/AIDS-syphilis co-infections: a retrospective multicentre study. Cent Eur J Public Health. 2019;27:223-8.

22. Aydın ÖA, Karaosmanoğlu HK, Sayan M, İnce ER, Nazlıcan Ö. Seroprevalence and risk factors of syphilis among HIV/AIDS pa-tients in Istanbul, Turkey. Cent Eur J Public Health. 2015;23:65-8. 
23. Sarıgül F, Üser Ü, Öztoprak N. HIV/AIDS Hastalarında Sifilis Koinfeksiyonu Seroprevalansı ve Risk Faktörleri. Klimik Derg. 2019;32:161-4.

24. Erdinc FS, Dokuzoguz B, Unal S, Komur $S$, Inkaya AC, Inan D, Karaoglan I, Deveci A, Celen MK, Kose S, Erben N, Senturk GC, Heper $Y$, Kutlu SS, Hatipoglu CA, Sumer S, Kandemir B, Sirmatel F, Bayindir Y, Yilmaz E, Ersoy Y, Kazak E, Yildirmak MT, Kayaaslan B, Ozden K, Sener A, Kara A, Gunal O, Birengel S, Akbulut A, Yetkin F, Cuvalci NO, Sargin F, Pullukcu H, Gokengin D, Multicentric Hiv Study Group. Temporal Trends in the Epidemiology of HIV in Turkey. Curr HIV Res. 2020;18:258-66.

25. Dougan S, Evans BG and Elford J. Sexually transmitted infections in Western Europe among HIV-positive men who have sex with men. Sex Transm Dis. 2007;34:783-90.

26. Pines HA, Wertheim JO, Liu L, Garfein RS, Little SJ, Karris MY. Concurrency and HIV transmission network characteristics among MSM with recent HIV infection. AIDS. 2016;30:2875-83.

27. Fujimoto K, Flash CA, Kuhns LM, Kim JY, Schneider JA. Social networks as drivers of syphilis and HIV infection among young men who have sex with men. Sex Transm Infect. 2018;94:365-71.

28. Adler MW. Sexually transmitted diseases control in developing countries. Genitourin Med. 1996;72:83-8.
29. Cohen MS, Chen YQ, McCauley M, Gamble T, Hosseinipour MC, Kumarasamy $\mathrm{N}$, Hakim JG, Kumwenda J, Grinsztejn B, Pilotto JHS, Godbole SV, Mehendale S, Chariyalertsak S, Santos BR, Mayer KH, Hoffman IF, Eshleman SH, Piwowar-Manning E, Wang L, Makhema J, Mills LA, de Bruyn G, Sanne I, Eron J, Gallant J, Havlir D, Swindells S, Ribaudo H, Elharrar V, Burns D, Taha TE, Nielsen-Saines K, Celentano D, Essex M, Fleming TR, HPTN 052 Study Team. Prevention of HIV-1 infection with early antiretroviral therapy. N Engl J Med. 2011;365:493-505.

30. Rodger AJ, Cambiano V, Bruun T, Vernazza P, Collins S, van Lunzen J, Corbelli GM, Estrada V, Geretti AM, Beloukas A, Asboe D, Viciana P, Gutiérrez F, Clotet B, Pradier C, Gerstoft J, Weber R, Westling K, Wandeler G, Prins JM, Rieger A, Stoeckle $M$, Kümmerle T, Bini T, Ammassari A, Gilson R, Krznaric I, Ristola M, Zangerle R, Handberg P, Antela A, Allan S, Phillips AN, Lundgren J, PARTNER Study Group. Sexual activity without condoms and risk of HIV transmission in serodifferent couples when the HIV-positive partner is using suppressive antiretroviral therapy. JAMA. 2016;316:171-81.

31. Grulich A, Bavinton BR, Jin F, Prestage G, Zablotska IB, Grinsztejn B, Phanuphak N, Moore R, Koelsch KK. HIV transmission in male serodiscordant couples in Australia, Thailand and Brazil. 2015 Conference on Retroviruses and Opportunistic Infections (CROI), Seattle, USA, 2015. 